\title{
Dynamic scaling equation of state for nonequilibrium solution under gravity above consolute critical temperature
}

\author{
A.D.Alekhin, Yu.L.Ostapchuk \\ Physics Department, Taras Shevchenko National University of Kyiv, \\ 6 Glushkova Ave., 03680 Kyiv, Ukraine
}

Received August 11, 2001, in final form June 26, 2001

\begin{abstract}
Altitude and time dependence of nonequilibrium values of refractive index gradient for inhomogeneous methanol-hexane solution under gravity near consolute critical temperature was investigated in the work as system approaches equilibrium state. Based on these data there have been suggested scaling equations of nonequilibrium liquid under gravity for temperatures above consolute critical temperature. It has been shown that the scaling hypothesis is also valid for nonequilibrium solution close to the critical point for small values of order parameter.
\end{abstract}

Key words: scaling equation of state, nonequilibrium solution, gravitational effect, consolute critical point

PACS: 05.70.Jk, 64.30.tt, 64.60.Ht, 64.70.Ja

Several behaviour features of inhomogeneous liquids which are not observed in homogeneous systems had been detected for the first time earlier while studying the kinetics of equilibrium establishment for inhomogeneous liquid system under gravity close to the critical point for temperatures above the critical one $\left(T>T_{\mathrm{c}}\right)$. There has been discovered nonmonotonous temperature dependence of equilibrium time $t_{\mathrm{e}}(\Delta T)$ for inhomogeneous substance under gravity [1-4]. The greatest time $t_{\mathrm{e}}=\max$ corresponds to a temperature $\Delta T>0$ - not to the critical temperature $\Delta T=T-T_{\mathrm{c}}=0$. It was proved for the first time that time $t_{\mathrm{e}}$ depends not only on relaxation time $\tau\left(\rho_{\mathrm{c}}\right) \sim D^{-1} \sim \Delta T^{-\nu}[5-7]$ but also on the thickness of the layer $\Delta z$ of liquid with critical density $\rho_{\mathrm{c}}$ which varies with temperature as $\Delta z \sim$ $\Delta T^{\beta \delta}\left(t_{\mathrm{e}} \sim \tau \Delta z \sim(\Delta T)^{\beta \delta-\nu}[1,2]\right.$. There has been obtained the nonmonotonous altitude dependence of relaxation time $\tau(z)$ of refractive index gradient $\mathrm{d} n / \mathrm{d} z$ of inhomogeneous liquid under gravity [8,9]. Maximum value of the $\tau(z)$ does not correspond to the level $z=0$ with critical density $\rho_{\mathrm{c}}$ of the investigated substance but to a height $z \neq 0$, in the vicinity of which isotherms of refractive index gradient $\mathrm{d} n / \mathrm{d} z$ intersect each other. It is close to this intersection point that magnitudes of 
nonequilibrium values $\mathrm{d} n / \mathrm{d} z$ slowly vary with time when the system is passing to the equilibrium state. It was also detected for the first time $[8,9]$ that the relaxation properties of inhomogeneous liquid at a certain height $z$ are determined not by a single relaxation time but by the spectrum of times, which characterizes the whole inhomogeneous system under gravity.

The purpose of the present paper is to continue these experimental investigations for detection of kinetics peculiarities of equilibrium establishment in spatially inhomogeneous liquid systems close to the critical point; to develop the scaling equation of state for such a nonequilibrium system in external gravitational field.

Kinetics of equilibrium establishment for inhomogeneous binary methanol-hexane solution under gravity has been studied in the work by using refractometry technique at different temperatures above consolute critical temperature. Routine of the experiment and the experimental equipment were described in detail in the works $[8,10]$.

The binary methanol-hexane solution with critical mass fraction of methanol $c_{1}=0.314[11]$ was poured into temperature-controlled optical cell with parallel glass. The mass of the solution was such that the vapour-gas phase was held over the investigated substance at all temperatures under study. The height of liquid in the cell was $2 \mathrm{~cm}$. Solution was quickly heated for $1.5-2$ hour initially from doublephase state at room temperature $T=293 \mathrm{~K}$ to the consolute critical temperature $T_{\mathrm{c}}=307.1 \mathrm{~K}$. The temperature, at which the phase interface of the solution components disappeared was taken for the critical one. Refractive index gradient and intensity of scattered light at this temperature at the height $z=0$, at which critical values of inhomogeneous substance of density and concentration are realized, attain the maximum value. The investigated solution had been thermostated at this temperature with an accuracy $\pm 0.01 \mathrm{~K}$ for a long time, almost a day, until the refractive index gradient $\mathrm{d} n / \mathrm{d} z$ ceased to vary at all heights of inhomogeneous solution. Thermostating system allowed to maintain the height gradient of temperature not higher than $\mathrm{d} T / \mathrm{d} z=(1 \div 2) \cdot 10^{-3} \mathrm{~K} / \mathrm{cm}[12,13]$, which were measured by two resistance thermometers set in the top end and the bottom of the cell.

After that the given inhomogeneous but equilibrium system was quickly heated for 10-15 min from the critical temperature to various temperatures $T_{i}>T_{\mathrm{c}}$ and thermostated for a long time until it turned into another equilibrium state at temperature $T_{i}$. The period of time, after which the value $\mathrm{d} n / \mathrm{d} z(z)$ practically didn't change, was taken for the equilibrium time $t_{\mathrm{e}}$ [14]. These temperature jumps $\Delta T=T_{i}-T_{\mathrm{c}}$ differed from each other and varied in the range of $\Delta T$ from $0.1 \mathrm{~K}$ to $20 \mathrm{~K}$.

The altitude dependence of the refractive index gradient $\mathrm{d} n / \mathrm{d} z(z)$ of the investigated solution was continuously varying with the time $t$ while thermostating. This change of $\mathrm{d} n / \mathrm{d} z(z)$ with time $t$ at the temperature $\Delta T=T_{i}-T_{\mathrm{c}}=3.96 \mathrm{~K}$ is given as an example in figure 1.

Figure 1 shows kinetics of change of symmetrized values of refractive index gradient $\overline{\mathrm{d} n / \mathrm{d} z}(z, t)=1 / 2 \cdot(\mathrm{d} n / \mathrm{d} z(z>0)+\mathrm{d} n / \mathrm{d} z(z<0)$ at different heights $z$ of the cell with inhomogeneous methanol-hexane solution at the temperature 


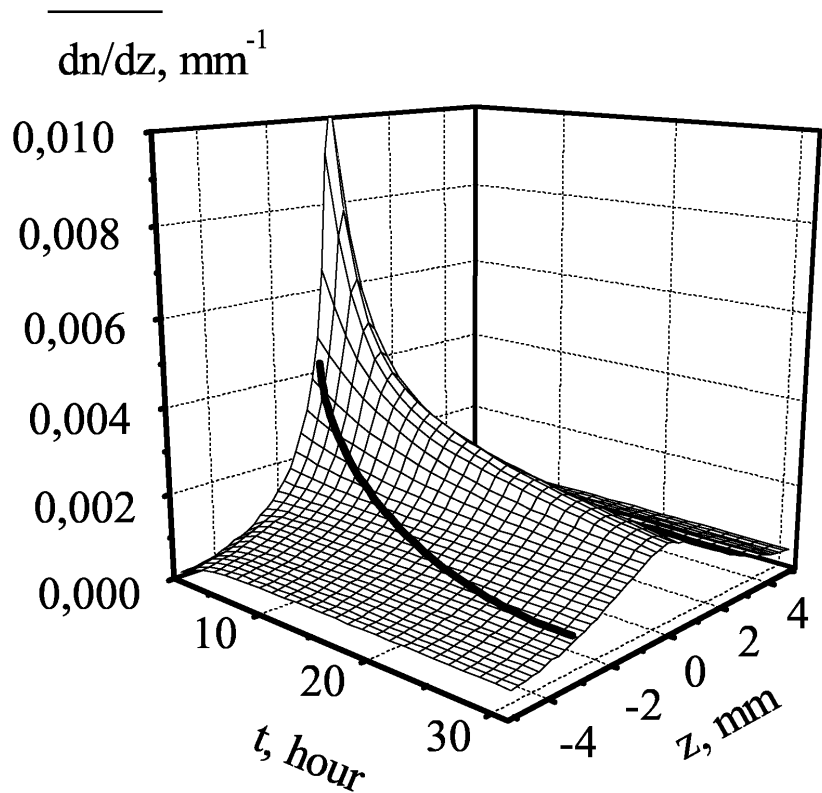

(a)

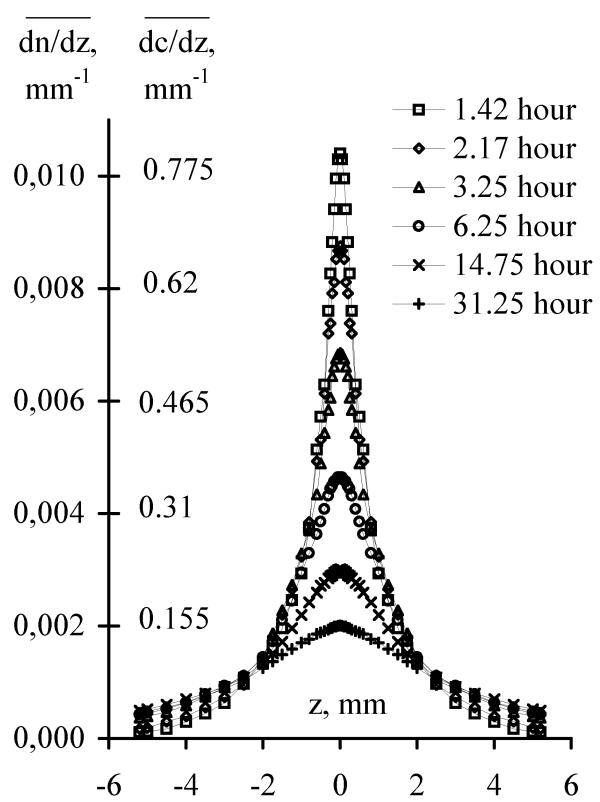

(b)

Figure 1. Kinetics of change of altitude dependence of symmetrized values of refractive index gradient $\overline{\mathrm{d} n / \mathrm{d} z}$ and concentration gradient $\overline{\mathrm{d} c / \mathrm{d} z}$ for inhomogeneous methanol-hexane solution at temperature $\Delta T=3.96 \mathrm{~K}$ : (a) 3-dimensional surface $\overline{\mathrm{d} n / \mathrm{d} z}(z, t)$; (b) sections of the $\overline{\mathrm{d} n / \mathrm{d} z}(z, t)$ surface by planes $t=$ const for different times $t$ after the beginning of thermostating.

$\Delta T=T_{i}-T_{\mathrm{c}}=3.96 \mathrm{~K}$ as the system approaches equilibrium state. The values $\mathrm{d} n / \mathrm{d} z(z)$ were taken at heights $z$ symmetric with respect to the level $z=0$, where the critical values of density and concentration of solution are realized. The action of the mentioned temperature gradient $\mathrm{d} T / \mathrm{d} z=(1 \div 2) \cdot 10^{-3} \mathrm{~K} / \mathrm{cm}$ at this temperature cannot considerably influence the magnitude of refractive index gradient and the kinetics of its change with time according to calculations [13]. As it is obvious from the figure, with time $t$ increasing, the value of refractive index gradient at the height $z=0$, where critical values of density and concentration are realized, decreases; and at the heights $z \geqslant 0.2 \mathrm{~cm}$ it increases on the contrary. This results in intersection of altitude dependencies $\overline{\mathrm{d} n / \mathrm{d} z}(z, t)$ in the vicinity of the height $z \approx 0.2 \mathrm{~cm}$.

By means of Lorentz-Lorenz formula [15]

$$
\frac{n^{2}-1}{n^{2}+2}=\rho_{s}\left(c_{1} \Delta r+r_{2}\right)
$$

these data (figure 1) were used to analyze kinetics behaviour of establishment of equilibrium concentration gradient values of the investigated solution (figure 1):

$$
\frac{\overline{\mathrm{d} c(z)}}{\mathrm{d} z}=\frac{1}{\rho_{s} \Delta r} \cdot \frac{6 n}{\left(n^{2}+2\right)^{2}} \cdot \frac{\overline{\mathrm{d} n(z)}}{\mathrm{d} z} .
$$

Here $c_{1}$ is mass concentration of methanol in the solution; $\Delta r=r_{1}-r_{2} ; r_{1}, r_{2}$ are specific refractions of the components; $\rho_{s}$ is density of the solution. 


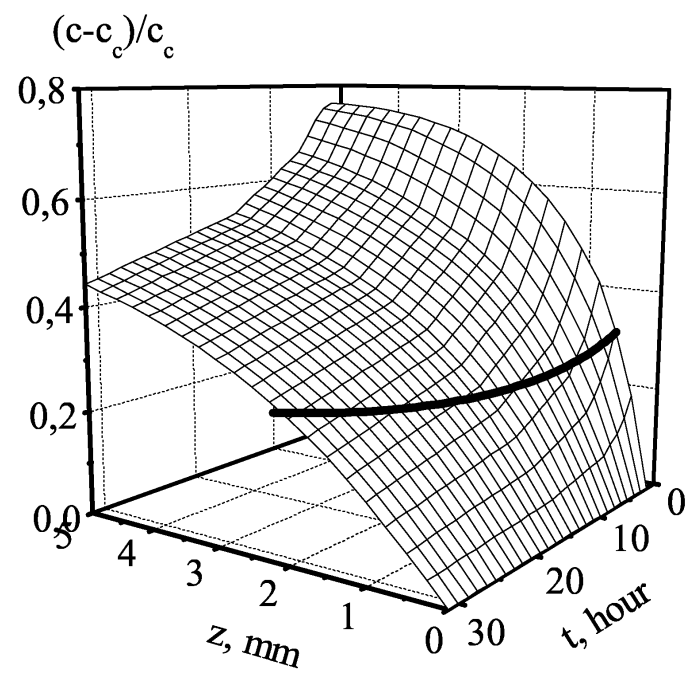

(a)

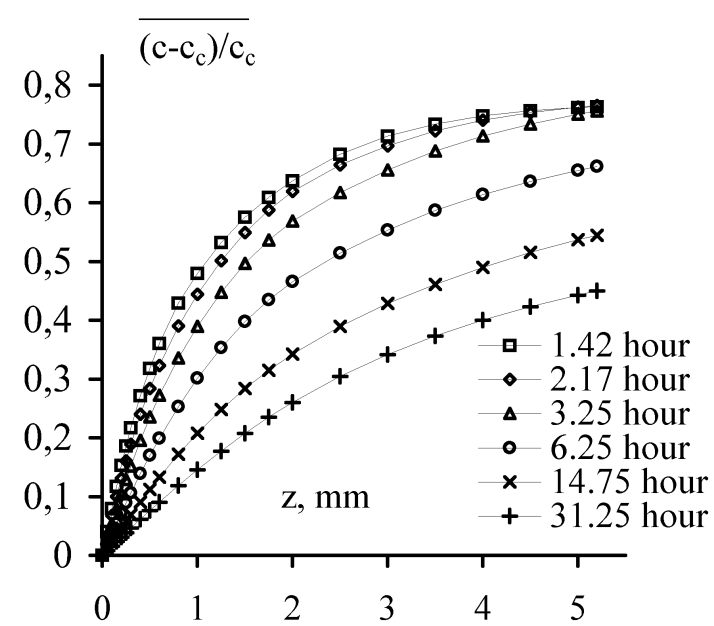

(b)

Figure 2. Kinetics of change of altitude dependence of concentration for methanol-hexane solution at temperature $\Delta T=3.96 \mathrm{~K}$ : (a) 3-dimensional surface $\overline{\left(c-c_{\mathrm{c}}\right) / c_{\mathrm{c}}}(z, t)$; (b) sections of the $\overline{\left(c-c_{\mathrm{c}}\right) / c_{\mathrm{c}}}(z, t)$ surface by planes $t=$ const for different times $t$ after the beginning of thermostating.

Concentration deviations from critical value (value of order parameter of solution) $\overline{\Delta c^{*}}(z)=\overline{\left(c-c_{\mathrm{c}}\right) / c_{\mathrm{c}}}=1 / c_{\mathrm{c}} \cdot \int_{0}^{z} \overline{\mathrm{d} c / \mathrm{d} z} \mathrm{~d} z$ were obtained by integrating the derivative $\overline{\mathrm{d} c / \mathrm{d} z}(z, t)$ over height $z$. Therefore, altitude distribution of the concentration $\bar{c}(z, t)=c_{\mathrm{c}} \pm \overline{\Delta c}(z, t)$ was obtained as well. These data are shown in figure 2 .

The above presented experimental data of kinetics of equilibrium establishment of concentration gradient values $\overline{\mathrm{d} c / \mathrm{d} z}(z, t)$ and concentrations $\overline{\Delta c}(z, t)$ were used to build-up dynamic scaling equations of state for substance under gravity close to the critical point for temperatures above the critical one $T>T_{\mathrm{c}}$. The analysis of altitude and time dependencies behaviour of the obtained data $\overline{\mathrm{d} c / \mathrm{d} z}(z, t)$ and $\overline{\Delta c}(z, t)$ has allowed to suppose that similar equilibrium properties of substance for certain temperatures $\theta=\left(T-T_{\mathrm{c}}\right) / T_{\mathrm{c}}$ correspond to these nonequilibrium characteristics of solution at different times $t$.

This suggestion follows from qualitatively the same time behaviour of nonequilibrium values $\overline{\mathrm{d} n / \mathrm{d} z}(z, t)$ (figure 1 ) and temperature dependencies of equilibrium values $\overline{\mathrm{d} n / \mathrm{d} z}(z, \theta)[16,17]$. The analysis of the obtained data has showed that magnitude $\overline{\mathrm{d} n / \mathrm{d} z}(z, t)$ at the level $z=0$ decreases by power relation $\mathrm{d} n / \mathrm{d} z(z=0, t) \sim t^{-x}$ $(x=0.543)$ with time increasing. At the levels $z>z_{0} \approx 0.2 \mathrm{~cm}$ with time $t$ increasing the value $\overline{\mathrm{d} n / \mathrm{d} z}$ also increases. The same temperature dependence of equilibrium values of derivative $\overline{\mathrm{d} n / \mathrm{d} z}(\theta)$ and intensity of scattered light $I \sim \mathrm{d} \rho / \mathrm{d} \mu(\theta)$ at the different heights of inhomogeneous system is confirmed by all existent experimental data $[16,17]$ and theoretical accounts of gravity effect [17] based on the modern theory of phase transition. 


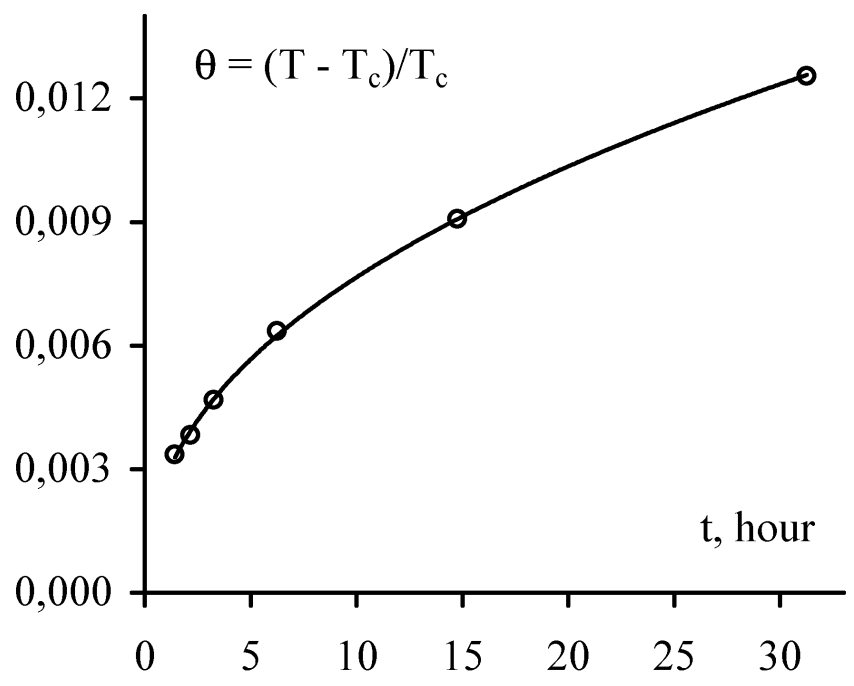

Figure 3. Relationship between time, for which altitude distributions $\mathrm{d} n / \mathrm{d} z(z, t)$ of nonequilibrium liquid correspond, and respective temperature of equilibrium states of inhomogeneous liquid.

Proceeding from these qualitatively same time $\overline{\mathrm{d} n / \mathrm{d} z}(z, t) \sim t^{-x}$ and temperature dependencies $\overline{\mathrm{d} n / \mathrm{d} z}(z, \theta) \sim \theta^{-\gamma}$ for the case $\overline{\mathrm{d} n / \mathrm{d} z}\left(z, t_{i}\right)=\overline{\mathrm{d} n / \mathrm{d} z}\left(z, \theta_{i}\right)$ it is possible to propose the following relation between temperature $\theta_{i}$ of equilibrium value $\overline{\mathrm{d} n / \mathrm{d} z}\left(z, \theta_{i}\right)$ and time $t_{i}$ of nonequilibrium values $\overline{\mathrm{d} n / \mathrm{d} z}\left(z, t_{i}\right)$ :

$$
\frac{\overline{\mathrm{d} n / \mathrm{d} z}\left(z=0, t_{i}\right)}{\overline{\mathrm{d} n / \mathrm{d} z}\left(z=0, t_{\mathrm{e}}\right)}=\left(\frac{t_{i}}{t_{\mathrm{e}}}\right)^{-x}=\frac{\overline{\mathrm{d} n / \mathrm{d} z}\left(z=0, \theta_{i}\right)}{\overline{\mathrm{d} n / \mathrm{d} z}\left(z=0, \theta_{\mathrm{e}}\right)}=\left(\frac{\theta_{i}}{\theta_{\mathrm{e}}}\right)^{-\gamma} .
$$

Here $\overline{\mathrm{d} n / \mathrm{d} z}\left(z=0, t_{\mathrm{e}}\right) \equiv \overline{\mathrm{d} n / \mathrm{d} z}\left(z=0, \theta_{\mathrm{e}}\right)$ are experimentally measured equilibrium values of refractive index gradient at the temperature $\Delta T=3.96 \mathrm{~K}$, where time $t_{\mathrm{e}}=31.25$ hour. From expression (3) the relation between $t_{i}$ and $\theta_{i}$ follows:

$$
\theta_{i}\left(t_{i}\right)=\theta_{\mathrm{e}}\left(\frac{t_{i}}{t_{\mathrm{e}}}\right)^{x / \gamma}=C \cdot t_{i}^{n}
$$

This dependence is shown in figure 3. It results from these data that coefficient $C=\theta_{\mathrm{e}} / t_{\mathrm{e}}^{x / \gamma}=2.82 \cdot 10^{-3}$ hour $^{-n}$ and exponent $n=x / \gamma=0.434$.

Given this, based on the received data $\overline{\mathrm{d} n / \mathrm{d} z}(z, t)$ there were suggested the scaling equations of a nonequilibrium fluid under gravity in a differential and integral view:

$$
\begin{aligned}
\frac{\overline{\mathrm{d} c}}{\overline{\mathrm{d} z}} & =\theta^{-\gamma} \cdot f_{1}\left(z^{*}\right)=t^{-n \gamma} \cdot f_{1}^{\prime}\left(z^{* \prime}\right), \\
\overline{\Delta c^{*}} & =\theta^{\beta} \cdot f_{2}\left(z^{*}\right)=t^{n \beta} \cdot f_{2}^{\prime}\left(z^{* \prime}\right) .
\end{aligned}
$$

Here $f_{1}\left(z^{*}\right)$ and $f_{1}^{\prime}\left(z^{* \prime}\right) ; f_{2}\left(z^{*}\right)$ and $f_{2}^{\prime}\left(z^{* \prime}\right)$ are scaling functions of the scaling arguments $z^{*}=z / \theta^{\beta \delta}$ and $z^{* \prime}=z / t^{n \beta \delta}$ respectively (here $\gamma \approx 5 / 4 ; \beta \approx 1 / 3 ; \delta \approx 5$ are critical exponents of the fluctuation theory [5-7]. 


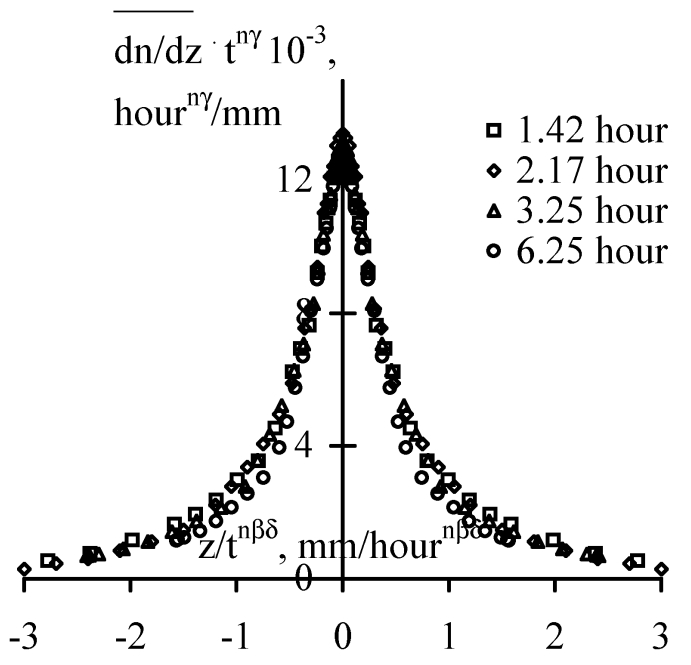

(a)

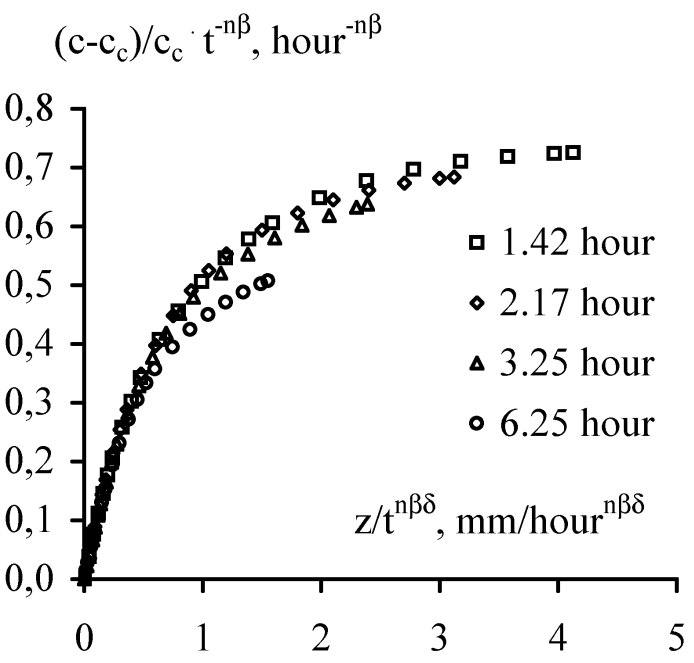

(b)

Figure 4. The scaling functions of concentration gradient (a) and concentration (b) for all investigated values of concentrations $\left(\overline{\Delta c^{*}}=0 \div 0.8\right)$.

If the scaling hypothesis [5-7] exists for nonequilibrium systems close to critical point, the transition to the scaling equation of state should transform 3-dimensional surfaces $\overline{\mathrm{d} c / \mathrm{d} z}(z, t)$ and $\overline{\Delta c^{*}}(z, t)$ to the scaling lines $f_{1}^{\prime}\left(z^{* \prime}\right)$ and $f_{2}^{\prime}\left(z^{* \prime}\right)$. The view of these scaling functions is shown in figure $4 \mathrm{a}, \mathrm{b}$.

To build-up these functions there have been used experimental data $\overline{\mathrm{d} c / \mathrm{d} z}(z, t)$ and $\overline{\Delta c^{*}}(z, t)$ in the whole range of the investigated concentrations: from the small ones $\overline{\Delta c^{*}}(z, t) \leqslant(0 \div 0.3) \ll 1$ to the large ones $\overline{\Delta c^{*}}(z, t) \leqslant(0.4 \div 0.8)$. It has had an influence on the build-up of a scaling equation of state. As it is visible from figure 4 the surfaces $\overline{\mathrm{d} c / \mathrm{d} z}(z, t)$ and $\overline{\Delta c^{*}}(z, t)$ are not transformed into single lines in the whole range of heights $z$ and times $t$. It is due to the fact that the Ginzburg criterion $G_{i} \ll 1[19]$ is defaulted for large concentrations $\overline{\Delta c^{*}}(z, t) \leqslant(0.4 \div 0.8) \leqslant 1$ according to [5]. That is, the system falls out from fluctuation area and cannot be described by scaling equation of state. That is why we have selected from the experimental data $\overline{\mathrm{d} c / \mathrm{d} z}(z, t)$ and $\overline{\Delta c^{*}}(z, t)$ the range of heights $z$ and times $t$, for which only small concentrations $\overline{\Delta c^{*}}(z, t) \leqslant 0.3 \ll 1$ correspond. The scaling functions $f_{1}^{\prime}\left(z^{* \prime}\right)$ and $f_{2}^{\prime}\left(z^{* \prime}\right)$, built-up specially for this range of concentrations, are shown in figures $5 \mathrm{a}, \mathrm{b}$.

As it is obvious, it is only for these small concentrations that the three-dimensional surfaces $\overline{\mathrm{d} c / \mathrm{d} z}(z, t)$ and $\overline{\Delta c^{*}}(z, t)$ really converge to the single lines $f_{1}^{\prime}\left(z^{* \prime}\right)$ and $f_{2}^{\prime}\left(z^{* \prime}\right)$ of the scaling argument $z^{* \prime}=z / t^{n \beta \delta}$. These lines can be described by the following scaling equations:

$$
\begin{aligned}
& f_{1}^{\prime}\left(z^{* \prime}\right)=\sum_{n=0}^{\infty} A_{n}\left(z^{* \prime}\right)^{2 n} \approx A_{0}-A_{1}\left(z^{* \prime}\right)^{2}+A_{2}\left(z^{* \prime}\right)^{4}+\ldots \\
& f_{2}^{\prime}\left(z^{* \prime}\right)=\sum_{n=0}^{\infty} B_{n}\left(z^{* \prime}\right)^{2 n+1} \approx B_{0}\left(z^{* \prime}\right)-B_{1}\left(z^{* \prime}\right)^{3}+\ldots
\end{aligned}
$$




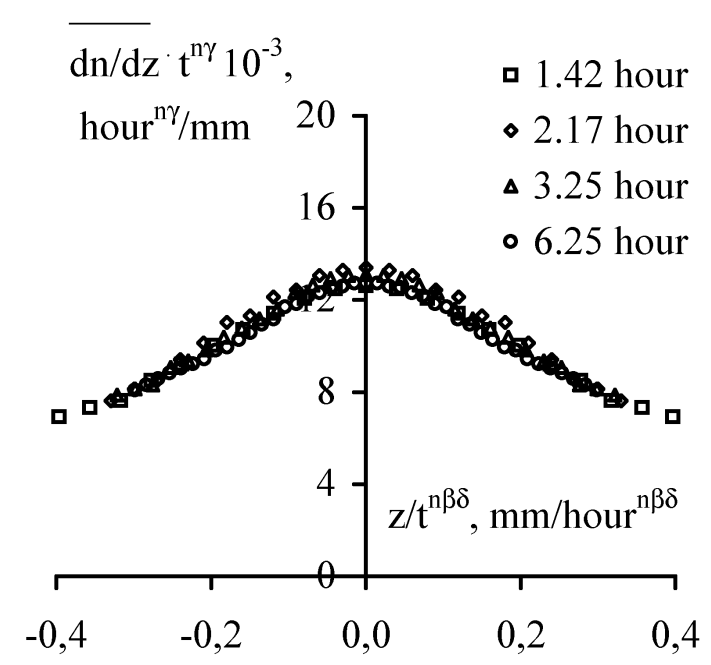

(a)

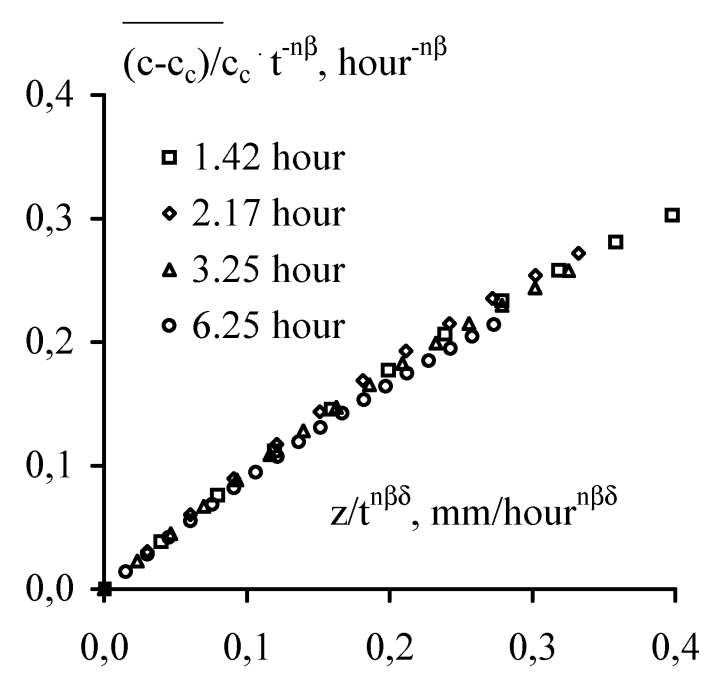

(b)

Figure 5. The scaling functions of concentration gradient (a) and concentration (b) for small values of concentrations $\overline{\Delta c^{*}}=(0 \div 0.3) \ll 1$.

Here are

$$
\begin{aligned}
& A_{0}=(1.31 \pm 0.04) \cdot 10^{-2} \operatorname{hour}^{n \gamma} / \mathrm{mm} ; \\
& A_{1}=(7.95 \pm 0.05) \cdot 10^{-2} \operatorname{hour}^{2 n \beta \delta+n \gamma} / \mathrm{mm}^{3} \\
& A_{2}=(0.26 \pm 0.01) \text { hour }^{4 n \beta \delta+n \gamma} / \mathrm{mm}^{5} ; \\
& B_{0}=(0.95 \pm 0.03) \text { hour }^{n \beta \delta-n \beta} / \mathrm{mm} ; \\
& B_{1}=(1.2 \pm 0.2) \text { hour }^{3 n \beta \delta-n \beta} / \mathrm{mm}^{3} .
\end{aligned}
$$

In figures 1, 2 these surfaces are marked by thick lines, which bound concentrations $\overline{\Delta c^{*}} \leqslant 0.3 \ll 1$.

Thus, the analysis of the obtained results has shown that in the range of small concentrations $\overline{\Delta c^{*}}=(0 \div 0.3) \ll 1$ kinetics of equilibrium establishment in inhomogeneous nonequilibrium methanol-hexane system under gravity can be described by dynamic scaling equations of state of equilibrium systems [5]. Hence, based on the relation (4) it is possible to predict in advance not only nonequilibrium values $\overline{\mathrm{d} c / \mathrm{d} z}(z, t)$ and $\overline{\Delta c^{*}}(z, t)$ at different times $t$, but also to determine scaling functions $f_{1}\left(z^{*}\right)$ and $f_{2}\left(z^{*}\right)(5)$, (6) for equilibrium solution under gravity close to critical point.

The work was supported by the Ukrainian State Fund of Fundamental research.

\section{References}

1. Alekhin A.D. Kinetics of gravity effect establishment near critical point. // Ukr. J. Phys., 1986, vol. 31, No. 5, p. 720-723 (in Russian). 
2. Alekhin A.D., Abdikarimov B.Zh., Bulavin L.A. Kinetics of equilibrium gravity effect establishment close to critical consolute temperature of binary solution. // Ukr. J. Phys., 1991, vol. 36, No. 3, p. 387-390 (in Russian).

3. Alekhin A.D., Bulavin L.A., Konvay D.B., Malarenko D.I. The particularities of mass transfer of binary mixture components in supercritical exfoliation range. - In: The Fourth Asian Thermophysical Properties Conference. Tokyo, 1995, B3e3, p. 703-706.

4. Alekhin A.D., Bulavin L.A., Konvay D.B., Malarenko D.I. The particularities of binary mixture components movement near the exfoliation critical point. // Condens. Matter Phys., 1996, No. 8, p. 11-16.

5. Patashinskii A.Z., Pokrovskii V.L. Fluctuation Theory of Phase Transition. Pergamon, Oxford, 1979.

6. Wilson K. Feynman-graph expansion for critical exponents. // Phys. Rev. Lett., 1972, vol. 28 , p. 548.

7. Kadanoff L., Swift J. Transport coefficients near the liquid-gas critical point. // Phys. Rev., 1968, vol. 166, No. 1, p. 89-101.

8. Alekhin A.D., Malarenko D.I., Ostapchuk Yu.L. Relaxation time for inhomogeneous solution under gravity near the critical exfoliation temperature. // Ukr. J. Phys., 1997, vol. 42, No. 3, p. 314-316 (in Ukrainian).

9. Alekhin A.D., Abdikarimov B.Zh., Malarenko D.I., Ostapchuk Yu.L. Properties of the substance in the extremum points of relaxation time for an inhomogeneous solution near the critical exfoliation temperature. // Ukr. J. Phys., 1998, vol. 43, No. 10, p. 1244-1247 (in Ukrainian).

10. Alekhin A.D., Kondilenko I.I., Korotkov P.A. et al. Deflection of light due to the gravitational effect close to critical point. // Optics and spectr., 1977, vol. 42, No. 4, p. 704-709 (in Russian).

11. Kasapova N.L., Pozharskaya G.I., Kolpakov Yu.D., Skripov V.P. Determination of spinodal in demixing solution n-hexane-methanol by using light scattering. // JPhCh, 1983, vol. LVII, No. 9, p. 2182-2185 (in Russian).

12. Alekhin A.D. Studying of behaviour peculiarities of individual substances close to liquid-vapour critical point by light scattering method. Ph. D. Thesis, Taras Shevchenko National University of Kyiv, Ukraine, 1970, p. 231 (in Ukrainian).

13. Alekhin A.D., Bulavin L.A. Influence of temperature gradient on thermodynamic and correlation properties of inhomogeneous substance close to the critical point. // Ukr. J. Phys., 1990, vol. 35, No. 12, p. 1817-1826 (in Russian).

14. Alekhin A.D., Ostapchenko S.G., Svydka D.B., Malarenko D.I. Spectral kinetic and correlation characteristics of inhomogeneous mixtures in the vicinity of the point of stratification. - In: Light Scattering and Photon correlation Spectroscopy. Edited by E.R.Pike and J.B.Abbiss. NATO ASI Series. 1996, p. 441-460.

15. Volkenshtein M.B. Molecular Optics. Moscow, Gostekhizdat, 1944 (in Russian).

16. Golik A.Z., Shymansky Yu.I., Alekhin A.D. at al. Investigation of gravity effect close to the critical point of individual substances and solutions. - In: Equation of State of Gases and Liquids. To the 100th Anniversary of Van der Waals Equation. Moscow, Nauka, 1975, p. 189-217 (in Russian).

17. Shymanskaya E.T., Shymansky Yu.I., Golik A.Z. Investigation of critical state of pure substances by Teplor method. - In: Critical Phenomena and Fluctuations in Solutions. Moscow, Academy of Sciences of USSR publishing house, 1960, p. 171-188 (in Russian). 
18. Alekhin A.D., Krupsky N.P., Chalyi A.V. Properties of substance in the points of extremum susceptibility under constant fields in the vicinity of critical state. // JETP, 1972, vol. 63, No. 10, p. 1417-1420 (in Russian).

19. Ginzburg V.L. Some remarks about second-order phase transition and microskopical nature of ferroelectrics. // FTT, 1960, vol. 2, No. 9, p. 2031-2043 (in Russian).

\section{Динамічне рівняння стану нерівноважного розчину в гравітаційному полі вище критичної температури розшарування}

\section{О.Д.Альохін, Ю.Л.Остапчук}

Фізичний факультет,

Київський національний університет ім. Тараса Шевченка, 03680 Київ, просп. Глушкова, 6

Отримано 11 серпня 2001 р., в остаточному вигляді 26 червня $2001 \mathrm{p}$.

В роботі досліджена висотна та часова залежність нерівноважних значень градієнта показника заломлення неоднорідного розчину метанол-гексан у гравітаційному полі поблизу критичної температури розшарування при прямуванні системи до стану рівноваги. На основі цих даних запропоновані масштабні рівняння нерівноважної рідини в гравітаційному полі для температур вищих від критичної температури розшарування. Показано, що і для нерівноважного розчину поблизу критичної точки для малих значень параметра порядку системи виконується масштабна гіпотеза.

Ключові слова: масштабне рівняння стану, нерівноважний розчин, гравітаційний ефект, критична точка розшарування

PACS: $05.70 . J k, 64.30 .+t, 64.60 . \mathrm{Ht}, 64.70 . \mathrm{Ja}$ 
